\title{
A note on fixed point theorems in metric spaces
}

\section{DARIUSZ WARDOWSKI and NGUYEN VAN DUNG}

\section{ABSTRACT.}

In this paper, we show that the existence of fixed points in some known fixed point theorems in the literature is a consequence of the Banach contraction principle.

Acknowledgements. This work is partly discussed at The Dong Thap Seminar on Mathematical Analysis.

\section{REFERENCES}

[1] Agarwal, R. P., Meehan, M. and O'Regan, D., Fixed point theory and applications, Cambridge University Press, 2004

[2] Berinde, V., Iterative approximation of fixed points, Lecture Notes in Mathematics, Springer, 2006

[3] Bessaga, C., On the converse of the Banach fixed-point principle, Colloq. Math., 7 (1959), 41-43

[4] Bianchini, R. M. T., Su un problema di S. Reich aguardante la teoria dei punti fissi, Boll. Un. Mat. Ital., 5 (1972), 103-108

[5] Ćirić, L. B., Generalized contractions and fixed-point theorems, Publ. Inst. Math. (Beograd)(N.S.), 12 (1971), No. $26,19-26$

[6] Collaco, P. and Silva, J. C. E., A complete comparison of 25 contraction conditions, Nonlinear Anal., 30 (1997), No. 1, 471-476

[7] Goebel, K. and Reich, S., Uniform Convexity, Hyperbolic Geometry, and Nonexpansive Mappings, Marcel Dekker, New York, 1984

[8] Hardy, G. E. and Rogers, T. D., A generalization of a fixed point theorem of Reich, Canad. Math. Bull., 16 (1973), No. 2, 201-206

[9] Jachymski, J., A short proof of the converse to the contraction principle and some related resutls, Topol. Methods Nonlinear Anal., 15 (2000), 179-186

[10] Janos, L., A converse of Banach's contraction theorem, Proc. Amer. Math. Soc., 16 (1967), 287-289

[11] Kannan, R., Some results on fixed points II, Amer. Math. Monthly, 76 (1969), No. 4, 405-408

[12] Reich, S., Some remarks concerning contraction mappings, Canad. Math. Bull, 14 (1971), No. 1, 121-124

[13] Rhoades, B. E., A comparison of various definitions of contractive mappings, Trans. Amer. Math. Soc., 226 (1977), $257-290$

[14] Rhoades, B. E., A biased discussion of fixed point theory, Carpathian J. Math., 23 (2007), No. 1-2, 11-26

[15] Zamfirescu, T., Fix point theorems in metric spaces, Arch. Math. (Basel), 23 (1972), 292-298

DEPARTMENT OF NONLINEAR ANALYSIS

FACULTY OF MATHEMATICS AND COMPUTER SCIENCE

UNIVERSITY OF ŁODŹ

BANACHA 22, 90-238 ŁODŹ, POLAND

E-mail address: warddemath.uni.lodz.pl

Received: 14.07.2013; In revised form: 12.01.2014; Accepted: 23.04.2014

2010 Mathematics Subject Classification. 47H10, 54H25, 54D99, 54E99.

Key words and phrases. Fixed point, Banach contraction principle, metric space.

Corresponding author: Dariusz Wardowski; wardd@math.uni.lodz.pl 
FACULTY OF MATHEMATICS AND INFORMATION TECHNOLOGY

TEACHER EDUCATION

DONG THAP UNIVERSITY

Cao lanh City, Dong Thap Province, Vietnam

E-mail address: nvdungedthu.edu.vn 